\author{
Ante Samodol* \\ Hana Ćatović**
}

\title{
NOMINALNA KONVERGENCIJA I DINAMIKA PRILAGODBE REPUBLIKE HRVATSKE EUROPODRUČJU
}

\begin{abstract}
Sažetak
Da bi uvela euro kao službenu valutu, država kandidatkinja za europodručje mora ispuniti kriterije iz Maastrichta ili kriterije nominalne konvergencije i tako dokazati dostatnu razinu nominalne konvergencije. Kriteriji nominalne konvergencije svojevrsna su zaštita europodručja od rizika makroekonomskih nestabilnosti. Drugim riječima, dostatna razina nominalne konvergencije ukazuje na razinu spremnosti države kandidatkinje za integraciju u monetarni režim europodručja. U ovome radu konkretno je analizirana dinamika prilagodbe Republike Hrvatske procesu pristupanja europodručju. To je u prvom redu obuhvatilo monetarno i fiskalno pozicioniranje države u odnosu na nominalne kriterije. S obzirom na to da je tečaj eura i kune nominalno sidro cjelokupne dosadašnje monetarne politike, a devizne transakcije ključne u kreiranju i povlačenju primarnog novca, u središtu je ovog istraživanja tečaj kune prema euru. Iako se tečaj kune prema euru slobodno formira na deviznom tržištu ovisno o kretanjima ponude i potražnje za devizama, središnja banka uključuje se na devizno tržište kao posljedica jačeg kolebanja tečaja. Da Hrvatska narodna banka vodi politiku tzv. upravljanoga fluktuirajućeg tečaja i da je nominalni tečaj kune prema euru stabilan, pokazao je i model u kojem primjenom višestruke regresijske analize nezavisne varijable koje obilježavaju monetarne i fiskalne uvjete, uopće nemaju utjecaj na tečaj kune prema euru. To je očito bilo i ostaje primarno i isključivo pitanje tečajne politike središnje banke neovisno o interakciji tečaja s drugim varijablama ili ekonomskim i financijskim posljedicama koje donosi takva tečajna politika.
\end{abstract}

Ključne riječi: europodručje, nominalna konvergencija, konvergencijski kriteriji, tečaj eura i kune

\section{Uvod}

Rad predstavlja uvod u cjelovito istraživanje dinamike prilagodbe Republike Hrvatske $(\mathrm{RH}) \mathrm{u}$ vezi s njezinim pristupanjem europodručju. To je u prvom redu obuhvatilo

\footnotetext{
* doc. dr. sc. Ante Samodol, Libertas međunarodno sveučilište, asamodol@libertas.hr

** Hana Ćatović, Libertas međunarodno sveučilište, hcatovic@student.libertas.hr
} 
pozicioniranje Hrvatske u odnosu na nominalne monetarne i fiskalne kriterije nominalne konvergencije. Dakle, da bi se utvrdio trenutačni položaj RH u odnosu na europodručje, odnosno utvrdila postignuta razina nominalne konvergencije, monetarni i fiskalni pokazatelji RH stavili su se u odnos s nominalnim pokazateljima.

Dokazivanje dostatne razine nominalne konvergencije svojevrsna je zaštita europodručja od potencijalnih rizika makroekonomskih nestabilnosti koje bi mogle prouzročiti nedovoljno konvergirane zemlje. Vanjski šokovi narušavaju monetarnu i financijsku stabilnost. Te su dvije stabilnosti usko povezane te se može reći dajedna uvjetuje ili podupire drugu. S jedne strane, monetarna stabilnost koju Hrvatska narodna banka (HNB) postiže operativnim provođenjem monetarne politike, obavljanjem uloge banke svih banaka i osiguranjem nesmetanog odvijanja platnog prometa pridonosi smanjenju rizika za financijsku stabilnost, a financijska stabilnost s druge strane pridonosi očuvanju monetarne odnosno makroekonomske stabilnosti (HNB, 2015a). Ono za što se veže monetarna, a i cjelokupna ekonomska politika RH jest stabilnost tečaja. Dakle, nominalno sidro jest nominalni tečaj kune u odnosu na euro. Razlozi za odabir takvog sidra višestruki su, a baziraju se na specifičnostima hrvatskog gospodarstva - mala i otvorena ekonomija karakterizirana s visokim stupnjem euroizacije. Znači, održavanjem stabilnog tečaja kune u odnosu na euro, HNB djeluje na ostvarivanje svojeg primarnog cilja, stabilnosti cijena.

Unatoč makroekonomskim i financijskim šokovima koji su proizašli iz globalnog gospodarskog šoka izazvanog pandemijom korona virusa, Republika Hrvatska je 10. srpnja ove godine stupila u ERM II i tako napravila krupan korak prema uvođenju eura. Iz HNB-a ističu da je uvođenje eura moguće u 2023. Ulaskom Hrvatske u europodručje, HNB će postati članica Eurosustava što će obuhvatiti zamjenu instrumenata za provođenje monetarne politike s instrumentima Europske središnje banke (ESB). Jasno, preuzimanje jedinstvene monetarne politike od ESB-a povezano je s gubitkom samostalne monetarne politike HNB-a. Stupanj prilagodbe HNB-a na sustav ESB-a ovisit će o sličnostima ili različitostima njihovih operativnih okvira (Vlada Republike Hrvatske i HNB, 2017).

Operacije s kojima se HNB najčešće služi jesu devizne transakcije u svrhu održavanja stabilnog tečaja kune u odnosu na euro. S obzirom na specifičnost tečaja kao makroekonomskog cilja Hrvatske, višestrukom regresijskom analizom ispitani su utjecaji odabranih varijabli (novčana masa, inflacija, krediti trgovačkim društvima, krediti stanovništvu i udio duga u BDP-u) na tečaj. Dakle, ovim su se radom istražili monetarni i fiskalni pokazatelji Hrvatske u odnosu na nominalne, kako bi se odredio njezin položaj u odnosu na postizanje razine nominalne konvergencije, dostatne za pristupanje europodručju. Uz to, analizirana je dinamike prilagodbe Hrvatske u tom procesu. U tom istraživanju postavljene su dvije hipoteze, pri čemu je H1: makroekonomski pokazatelji i pokazatelji makroprudencijalne dijagnostike odstupaju od nomi- 
nalnih kriterija, a H2: financijska i monetarna stabilnost u uvjetima vanjskih šokova nisu eliminatorni kriteriji u dinamici prilagodbe.

\section{Pregled dosadašnjih istraživanja}

Svaka država kandidatkinja za Ekonomsku i monetarnu uniju (EMU) dužna je ispuniti kriterije nominalne konvergencije kako bi dokazala razinu nominalne konvergencije dostatnu za uvođenje eura kao nacionalne valute. Derado (2009) kao glavnu svrhu ispunjavanja kriterija nominalne konvergencije ističe ostvarivanje makroekonomske stabilnosti unutar monetarne integracije. Toader i Gîdiu (2012) ističu kako je s jedne strane uvođenje eura važan poticaj za nove članice EU (NMS) da osiguraju i očuvaju stabilnost cijena, dok je s druge strane ono i razlog stabilnog makroekonomskog okruženja svih članica europodručja. Kao glavnu svrhu ispunjavanja konvergencijskih uvjeta ističu pružanje sigurnosti da samo države članice EU-a s odgovarajućim ekonomskim uvjetima mogu biti dijelom europodručja. Marić (2015) navodi kako ispunjavanje kriterija nominalne konvergencije „jamči” spremnost zemlje za ulazak u europodručje nakon ulaska u EU. Nominalnu ekonomsku konvergenciju opisuje kao monetarnu i fiskalnu konvergenciju definiranu kriterijima u Ugovoru iz Maastrichta, formalno nužnu za ulazak države u europodručje. Autor ističe razliku između nominalne i realne konvergencije. Navodi kako ispunjeni nominalni konvergencijski kriteriji ne znače automatski veću realnu ekonomsku konvergenciju odnosno naglašava kako kriteriji nominalne konvergencije, monetarni i fiskalni, u kratkom roku ne bi trebali biti prioritet nego u funkciji realne konvergencije koja pojednostavljeno odražava stvarnu ekonomsku razvijenost i konkurentnost država kandidatkinja. U Ugovoru iz Maastrichta službeno se navode četiri kriterija: kriterij stabilnosti cijena, kriterij dugoročnih kamatnih stopa, kriterij stabilnosti tečaja i kriterij državnih financija. Međutim, kriterij državnih financija u sebi sadrži dva podkriterija - kriterij javnog duga i kriterij proračunskog manjka. U nastavku su opisani uvjeti za njihovo ispunjavanje.

Dakle, sukladno Ugovoru, država kandidatkinja koja želi ispuniti kriterij stabilnosti cijena ne smije imati stopu inflacije čija vrijednost prelazi referentnu vrijednost dobivenu kao stopu neponderiranog prosjeka od najviše triju država članica koje su ostvarile najbolje rezultate s obzirom na stabilnost cijena uvećanu za 1,5 postotni bod. Kriterij dugoročnih kamatnih stopa smatrat će se uspješno ispunjenim ukoliko prosječna stopa dugoročnih kamatnih stopa kandidatkinje ne prelazi referentnu vrijednost dobivenu kao prosječnu stopu dugoročnih kamatnih stopa u trima državama članicama EU-a koje su ostvarile najbolje rezultate s obzirom na stabilnost cijena uvećanu za 2 postotna boda. Zatim, kriterij stabilnosti tečaja smatrat će se uspješno ispunjenim ukoliko država kandidatkinja uspije održati stabilan tečaj nacionalne valute u odnosu 
na euro u kontinuitetu od dvije godine. Fluktuiranje tečaja dozvoljeno je unutar uobičajenih gabarita od $+/-15 \%$. Svi kriteriji ispituju se u vremenskom periodu od jedne godine, osim kriterija stabilnosti tečaja koji se ispituje u kontinuitetu od dvije godine.

Što se tiče fiskalnih kriterija nominalne konvergencije, njihove referentne vrijednosti konkretnije su definirane pa udio državnog deficita u BDP-u ne smije prelaziti 3 $\%$, dok udio državnog duga u BDP-u ne smije prelaziti $60 \%$. Prekoračenje tako definiranih vrijednosti omjera tolerira se ukoliko se omjer smanjuje u odgovarajućoj mjeri odnosno približava referentnoj vrijednosti zadovoljavajućim tempom. Tako je prema Izvješću o konvergenciji (2018) saldo proračuna opće države za 2017. bio u skladu s referentnom vrijednošću dok je omjer duga prelazio referentnu vrijednost, ali se pritom smanjivao u skladu s referentnom vrijednošću smanjenja duga iz Pakta o stabilnosti i rastu (PSR). Prema izvješću o konvergenciji (2020) saldo proračuna opće države za 2019. opet je bio u skladu s referentnom vrijednošću dok je omjer duga opet prelazio referentnu vrijednost, ali se opet smanjivao u skladu s referentnom vrijednošću smanjenja duga iz PSR-a. Unatoč poboljšanju u odnosu na ispunjenje fiskalnih kriterija koje se bilježi od 2015. te njihovom kolektivnom ispunjavanju uz iznimku iz PSR-a za omjer duga od 2017., iz ESB-a (2020) navode kako se zbog krize izazvane pandemijom koronavirusa očekuje znatno pogoršanje proračunske pozicije i znatno povećanje omjera duga u razdoblju od 2020. do 2021. Da je problem ostvarenja Hrvatske u odnosu na fiskalne kriterije već od prije poznat potvrđuje i Procedura prekomjernog deficita (EDP) koja je nad Hrvatskom bila otvorena od 2015. do lipnja 2017.

O dosegnutoj razini nominalne konvergencije države kandidatkinje za europodručje Vijeće Europske unije (Vijeće) izvještavaju Europska komisija (Komisija) i Europska središnja banka. Komisija i ESB izvještaje podnose najmanje jednom u dvije godine ili na zahtjev države kandidatkinje. Dakle, konačnu odluku o dostatnoj konvergenciji donosi Vijeće, nakon savjetovanja s Europskim parlamentom i održane rasprave u Europskom vijeću (ESB, 2018). Pozitivna konačna odluka Vijeća znači ulazak države kandidatkinje u europodručje. U tom trenutku nacionalna središnja banka države kandidatkinje postaje dijelom Eurosustava pa se instrumenti NSB-a zamjenjuju s onima od ESB-a, odnosno dolazi do preuzimanja jedinstvene monetarne politike koju kreira i koordinira ESB. Vlada Republike Hrvatske i HNB (2017) navode kako će stupanj zahtjevnosti operativne prilagodbe HNB-a na sustav ESB-a ovisiti o sličnostima ili o različitostima između dvaju sustava, odnosno njihovih operativnih okvira. Stoga navode kako će najmanji stupanj prilagodbe zahtijevati područje stalno raspoloživih mogućnosti i operacija na otvorenom tržištu, a najveći područje obvezne pričuve. Također, ESB raspolaže s daleko širom paletom nekonvencionalnih instrumenata i mjera s kojima se služi posljednjih desetak godina, dok je HNB započeo s provođenjem takve nekonvencionalne politike u ožujku ove godine. Gubitak autonomnosti u provođenju monetarne politike generalno se smatra najvećim troškom pristupanja za- 
jedničkom monetarnom području. Analiziranje prednosti i nedostataka od uvođenja zajedničke valute uobičajeno se zasniva na analizi koristi i troškova.

Ovaj rad fokusira se na najveći procijenjeni trošak od uvođenja eura u Hrvatskoj, koji iz Vlade Republike Hrvatske i Hrvatske narodne banke (2017) ocjenjuju kao gubitak samostalne monetarne politike te na uklanjanje valutnog rizika u gospodarstvu što ocjenjuju kao najveću korist od uvođenja eura. Primjenom teorije optimalnih valutnih područja (OCA), gubitak samostalne monetarne politike u kontekstu najvećeg troška od uvođenja eura (preuzimanje jedinstvene monetarne politike) analizirali su mnogi autori ističući kako on u Hrvatskoj ne bi trebao biti naglašen. Deskar-Škrbić et al. (2019) na tom tragu navode da, sukladno OCA teoriji, trošak gubitka samostalne monetarne politike ne bi trebao biti pretjerano naglašen ukoliko su ekonomski šokovi unutar monetarne unije koherentni. Uz to navode i da će takav trošak prema OCA teoriji biti malen za one zemlje kandidatkinje u kojima je ekonomska aktivnost uglavnom efekt istih šokova koji pokreću ekonomski razvoj u monetarnoj uniji. Brkić i Šabić (2018) navode kako OCA teorija predlaže par kriterija koje bi promatrana država kandidatkinja trebala zadovoljiti kako bi uspješno mogla funkcionirati u uvjetima zajedničke monetarne politike. Ističu kako se većina tih kriterija odnosi na utvrđivanje stupnja ekonomske integracije između promatrane države kandidatkinje i monetarne unije s obzirom na to da snažna ekonomska integriranost implicira manji rizik od asimetričnih šokova. Zatim, Kotorac et al. (2017) u svom radu zaključuju da su koherentnost poslovnih ciklusa i korelacija šokova ponude i potražnje između Hrvatske i europodručja relativno visoke. Nadalje zaključuju da su zajednički (simetrični) šokovi dominantniji pri objašnjavanju dinamike BDP-a, dok je doprinos asimetričnih šokova znatno manji. Konačno, ističu da rezultati analize ukazuju na konvergenciju šokova ponude i potražnje te poslovnih ciklusa između Hrvatske i članica jezgre europodručja. Dakle, svi doneseni zaključci argumenti su da zajednička monetarna politika nije toliko znatan trošak pristupanja europodručju za Hrvatsku.

Uklanjanje valutnog rizika u gospodarstvu najveća je korist od uvođenja eura za Hrvatsku, a proizlazi iz karakterističnosti hrvatskog gospodarstva koje je malo i otvoreno te karakterizirano visokim stupnjem valutne supstitucije u Hrvatskoj (HNB, 2015c). Čehulić i Hrbić (2019) navode da je euroizacija ekonomski opravdana u zemljama u kojima je prisutan manjak povjerenja u kreatore politike ili gdje izostaje povjerenje stanovništva u nacionalnu valutu. Autori ističu da je učinak euroizacije pozitivno odobren ako je ekonomija promatrane zemlje mala i otvorena te dobro integrirana s ostalim zemljama. Brkić i Šabić (2018) u svom radu naglašavaju iznimno visoku euroiziranost hrvatskog gospodarstva kao snažan argument u korist uvođenja eura ističući da je većina bankovnih kredita i depozita, kao i tri četvrtine javnog duga, denominirano u eurima ili je valutnom klauzulom vezano uz euro. Ćorić i Deskar-Šrbić (2017) navode da se valutni rizik javlja kada postoje valutne neusklađenosti 
u bilancama nekih ili svih institucionalnih sektora u gospodarstvu. Navode i da takve neusklađenosti ustraju onda kada su institucionalni sektori zaduženi u devizama, dok je njihova imovina i tokovi prihoda u domaćoj valuti. Iz toga proizlazi da bi deprecijacija domaće valute mogla potaknuti revalorizaciju duga prema gore i time naštetiti financijskoj i monetarnoj stabilnosti. Takve se neusklađenosti u RH odražavaju u svim sektorima. Brkić i Šabić (2018) ističu da u prilog pozitivnim učincima pristupanja Hrvatske europodručju također ide visok intenzitet vanjskotrgovinskih i financijskih odnosa RH s članicama europodručja. Stoga, iako je devizni tečaj kune u odnosu na euru i dosad bio poprilično stabilan, uvođenje eura ipak bi u potpunosti eliminiralo valutni rizik, kao i troškove vezane uz konverziju valuta i zaštitu od valutnog rizika. Utjecaj tečaja na izvoz u svom je radu istražio Sorić (2007). Autor je pomoću ARCH (1) modela ispitao dugoročnu vezu između volatilnosti i izvoza koja se pritom pokazala negativnom i prilično malenom. To znači da na povećanje volatilnosti tečaja kune hrvatski izvoznici reagiraju malim, ali postojećim smanjenjem izvoza pa autor zaključuje da hrvatski izvozni sektor karakterizira averzija prema riziku realnog tečaja kune.

\section{Republika Hrvatska i kriteriji nominalne konvergencije}

U tablicama 1 i 2 prikazana je pozicija RH u odnosu na kriterije nominalne konvergencije od godine njezina ulaska u EU, 2013. do 2019. Tako je iz tablice 1 vidljivo da kriterij stabilnosti cijena RH ispunjava u svim promatranim godinama osim u 2013., kriterij dugoročnih kamatnih stopa ispunjava u svim promatranim godinama dok se kriteriji stabilnosti tečaja nije mogao formalno ispitati jer je za njegovo ispitivanje potrebno da je kandidatkinja unutar ERM II.

Tablica 1. Položaj RH u odnosu na monetarne kriterije nominalne konvergencije

\begin{tabular}{|c|c|c|c|c|c|c|}
\hline $\begin{array}{l}\stackrel{0}{5} \\
\frac{5}{0} \\
0 \\
\end{array}$ & 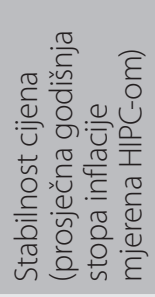 & 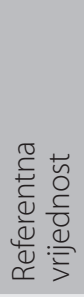 & 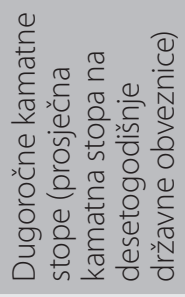 & 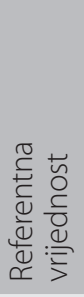 & 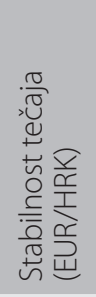 & 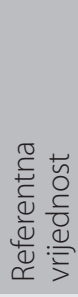 \\
\hline 2013. & 2,3 & 1,77 & 4,68 & 5,92 & 7,5786 & I \\
\hline 2014. & 0,2 & 1,26 & 4,05 & 4,84 & 7,6344 & I \\
\hline 2015. & $-0,3$ & 0,76 & 3,55 & 3,93 & 7,6137 & I \\
\hline 2016. & $-0,6$ & 1,03 & 3,49 & 3,81 & 7,5333 & I \\
\hline 2017. & 1,3 & 2,1 & 2,77 & 3,32 & 7,4637 & I \\
\hline 2018. & 1,6 & 2,23 & 2,17 & 3,19 & 7,4182 & I \\
\hline 2019. & 0,8 & 1,93 & 1,29 & 3,47 & 7,418 & I \\
\hline
\end{tabular}


Iz tablica 1 i 2 može se uočiti da se Hrvatska definitivno najlošije pozicionira u odnosu na kriterij državnih financija. Ipak od 2015. može se uočiti poboljšanje kriterija koje se očituje kontinuiranim smanjenjem proračunskog deficita (ostvarivanjem proračunskog suficita od 2017) i kontinuiranim smanjenjem javnog duga.

Tablica 2. Položaj RH u odnosu na fiskalne kriterije nominalne konvergencije

\begin{tabular}{|c|c|c|c|c|}
\hline Godina & $\begin{array}{c}\text { Proračunski } \\
\text { manjak (suficit ili } \\
\text { deficit proračuna } \\
\text { opće države kao } \\
\text { udio u BDP-u) }\end{array}$ & $\begin{array}{l}\text { Referentna } \\
\text { vrijednost }\end{array}$ & Javni dug & $\begin{array}{l}\text { Referentna } \\
\text { vrijednost }\end{array}$ \\
\hline 2013. & $-5,3$ & -3 & 81,2 & 60 \\
\hline 2014. & $-5,3$ & -3 & 84,7 & 60 \\
\hline 2015. & $-3,3$ & -3 & 84,3 & 60 \\
\hline 2016. & -1 & -3 & 80,8 & 60 \\
\hline 2017. & 0,8 & -3 & 77,8 & 60 \\
\hline 2018. & 0,2 & -3 & 74,7 & 60 \\
\hline 2019. & 0,4 & -3 & 73,2 & 60 \\
\hline
\end{tabular}

Zaključno, valja istaknuti da se tijekom 2020. kao posljedica Covid-19 pandemije udio javnog duga u BDP-u povećao pa tijekom zadnjeg kvartala iznosi više od $83 \%$ BDP-a. Očito je kako će se taj kriterij promatrati u svjetlu pandemije, a ne stvarne nominalne konvergencije. Kako bilo, komparativni prikaz osnovnog okvira provođenja monetarne politike HNB-a i ESB-a izgleda kao u tablici 3.

Tablica 3. Okvir za provođenje monetarne politike HNB-a i ECB-a

\begin{tabular}{|cc|}
\hline OPERATIVNI OKVIR HNB-A & OPERATIVNI OKVIR ESB-A \\
\hline Operacije na otvorenom tržištu & Operacije na otvorenom tržištu \\
\hline Obvezna pričuva & Stalno raspoložive mogućnosti \\
\hline Stalno raspoložive mogućnosti & Minimalna obvezna pričuva \\
Ostali instrumenti i mjere* & Nestandardni instrumenti i mjere \\
\hline *HNB se od 2020. koristi i nestandardnom mjerom programa otkupa obveznica. \\
\hline
\end{tabular}

$\mathrm{U}$ analizi operativnog okvira instrumenata monetarne politike HNB-a treba istaknuti da je obvezna pričuva bila ključni instrument monetarne politike. Tijekom zadnjih dvadesetak godina HNB je, osim standardnih oblika različitih stopa kunske (KOP) i devizne pričuve (DOP), uvodio i ukidao: posebnu obveznu pričuvu (POP), dopunsku obveznu pričuvu (DOP) i graničnu obveznu pričuvu (GOP). Uz to, sve do 
današnjih dana postoji i posebna stopa odnosa deviznih potraživanja i deviznih obveza (DP/DO $17 \%)$. Instrument eskontne stope nije se, osim nominalne objave, operativno ni koristio, a praktički sve do kraja 2015. politika otvorenog tržišta (obratni repo) nije ni postojala. Najmoćniji kanal djelovanja za otpuštanje i povlačenje kuna bio je kanal obvezne pričuve. Na taj način, HNB je sve do 2016. dominantno održavao stabilnost kolebanja tečaja. Tek od 2016. HNB je započeo sa značajnijim operacijama obratnih repo poslova s bankama, a s druge se strane $\mathrm{u}$ isto vrijeme tečajna politika provodila po principu: kad kuna jača, HNB kupuje devize; kad kuna slabi HNB prodaje devize. Događaj koji je doveo u opasnost takav način kreiranja i povlačenja primarnog novca i koji je ugrozio međunarodne devizne pričuve jest pandemija koronavirusa. Iako je RH ulaskom u ERM II praktički izašla iz „političke sfere odlučivanja” o ulasku u Europsku monetarnu uniju, ekonomska politika RH, a time izravno i provođenje monetarne politike i dalje ovisi o političkim odlukama EU o potporama za opravak od pandemije. Štoviše, sva očekivanja očuvanja gospodarske aktivnosti RH zasnivanju se na očekivanoj pomoći iz EU, što HNB-u upravo omogućuje provođenje dosadašnje vlastite tečajne politike.

S obzirom na to da je: a) pandemija promijenila sve dosadašnje poznate obrasce ponašanja realnog i monetarnog sektora, b) RH od 10. srpnja 2020. formalno uključena u Europski tečajni mehanizam II (ERM II), c) utvrđen središnji paritet između kune i eura koji iznosi 7,53450 kuna za euro uz standardnu fluktuacije $+/-15 \%$, valjalo je oblikovati model koji bi pokazao da je i dosadašnja tečajna politika HNB-a i tečaj euro/kuna bio ključni cilj kojem su podređene sve mjere središnje banke i kojemu su prinašane sve žrtve gospodarske strukture i razvitka $\mathrm{RH}$.

\section{Metodologija i skup podataka}

U svrhu procjene utjecaja odabranih nezavisnih varijabli: novčane mase, inflacije, kredita stanovništvu, kredita trgovačkim društvima i udjela duga u BDP-u na tečaj kao zavisnu varijablu, u radu je korištena višestruka regresijska analiza. Višestrukom regresijskom analizom istražila se linearnost ili nelinearnost između nezavisnih varijabli i zavisne varijable. Opći oblik jednadžbe višestruke regresijske analize zapisuje se kao:

$$
E(Y)=\beta_{0}+\beta_{1} x_{1}+\beta_{2} x_{2}+\cdots \beta_{p} x_{p}
$$

pri čemu je $E(Y)$ zavisna varijabla, $\beta_{0}$ odsječak na y-osi (vrijednost koju $E(Y)$ poprima kada su sve nezavisne varijable jednake nuli, $\beta_{1}-\beta_{p}$ koeficijenti smjera pravca, a $x_{1}-x_{p}$ nezavisne varijable. Nadalje, opći oblik procijenjene jednadžbe višestruke regresijske analize zapisuje se kao:

$$
\hat{Y}=b_{0}+b_{1} x_{1}+b_{2} x_{2}+\cdots b_{p} x_{p}
$$


pri čemu su $b_{1}-b_{p}$ procijenjene vrijednosti koeficijenata $\beta_{1}-\beta_{p}$, a $\hat{Y}$ procijenjena vrijednost zavisne varijable $E(Y)$. Konačno, jednadžba modela višestruke regresijske analize zapisuje se kao:

$$
Y=\beta_{0}+\beta_{1} x_{1}+\beta_{2} x_{2}+\cdots \beta_{p} x_{p}+\varepsilon
$$

gdje dodatni član $\varepsilon$ označava pogrešku.

Nakon provedene višestruke regresijske analize i eliminacije nesignifikantnih varijabli, u radu se iskoristila jednostruka regresijska analiza kako bi se posebno ispitao utjecaj nezavisne varijable udjela duga u BDP-u na tečaj. Zatim se u svrhu ispitivanja signifikantnosti takvog modela iskoristila jednosmjerna analiza varijance (one-way ANOVA). Set podataka korišten u regresijskoj analizi u ovom radu analizi prikazan je tablicom 4 .

Tablica 4. Tečaj euro/kuna kao zavisna varijabla i druge nezavisne varijable, 2002.-2019.

\begin{tabular}{|ccccccc|} 
Godine & EUR/HRK & $\begin{array}{c}\text { M1 } \\
\text { (mlrd. HRK) }\end{array}$ & $\begin{array}{c}\text { Inflacija } \\
(\%)\end{array}$ & $\begin{array}{c}\text { Krediti trgova- } \\
\text { čkim drustvima } \\
\text { (mlrd. HRK) }\end{array}$ & $\begin{array}{c}\text { Krediti } \\
\text { stanovništvu } \\
\text { (mlrd. HRK) }\end{array}$ & $\begin{array}{c}\text { Udio duga opće } \\
\text { države u BDP } \\
(\%)\end{array}$ \\
\hline 2002. & 7,4423 & 31 & 1,7 & 51,7 & 43,2 & 37 \\
\hline 2003. & 7,6469 & 34 & 1,8 & 53,8 & 55,2 & 39 \\
\hline 2004. & 7,6712 & 35 & 2,1 & 58,6 & 65,6 & 41 \\
\hline 2005. & 7,3756 & 39 & 3,3 & 67 & 79,1 & 41 \\
\hline 2006. & 7,3451 & 49 & 3,2 & 83,4 & 97 & 39 \\
\hline 2007. & 7,3251 & 58 & 2,9 & 92,3 & 115,1 & 37 \\
\hline 2008. & 7,3244 & 55 & 6,1 & 102,8 & 129,4 & 39 \\
\hline 2009. & 7,3062 & 47 & 2,4 & 104,9 & 125,8 & 49 \\
\hline 2010. & 7,3852 & 48 & 1,1 & 107,7 & 130,2 & 58 \\
\hline 2011. & 7,5304 & 51 & 2,3 & 116,8 & 131,6 & 64 \\
\hline 2012. & 7,545 & 52 & 3,4 & 103,2 & 129,8 & 70 \\
\hline 2013. & 7,6376 & 58 & 2,2 & 102,5 & 127,4 & 81 \\
\hline 2014. & 7,6615 & 63 & $-0,2$ & 98,4 & 126,5 & 85 \\
\hline 2015. & 7,635 & 71 & $-0,5$ & 93,5 & 124,5 & 84 \\
\hline 2016. & 7,5578 & 83 & $-1,1$ & 92,9 & 117,6 & 81 \\
\hline 2017. & 7,5136 & 99 & 1,1 & 89,9 & 119 & 78 \\
\hline 2018. & 7,4176 & 120 & 1,5 & 83 & 124 & 75 \\
\hline 2019. & 7,4426 & 137 & 0,8 & 83 & 129 & 73 \\
\hline
\end{tabular}

Izvor: www.hnb.hr. Statistike.

Podaci iz tablice 4 prikazani na slici 1 kao kretanja makroekonomskih pokazatelja i pokazatelja makroprudencijalne dijagnostike Republike Hrvatske za razdoblje od 2002. do 2019. nalaze se u nastavku. 
Slika 1. Kretanje makroekonomskih varijabli i pokazatelja makroprudencijalne dijagnostike

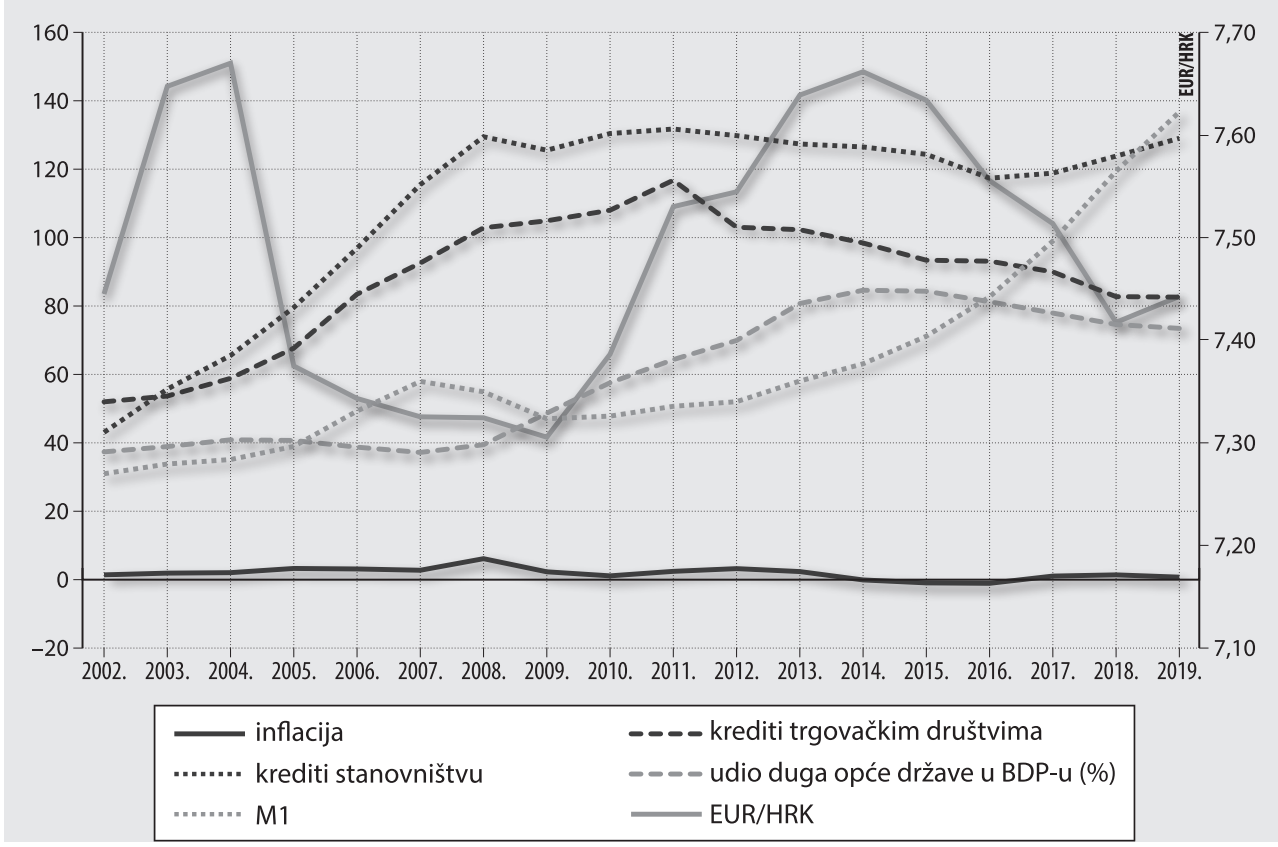

Izvor: autori.

\section{Rezultati i diskusija}

Održavanjem stabilnog tečaja HNB utječe na postizanje primarnog cilja - stabilnost cijena. Pritom se prvenstveno služila deviznim transakcijama (kupnjom ili prodajom deviza), kreirajući ili povlačeći primarni novac ovisno o potrebama tečaja. Slab stupanj kolebljivosti tečaja kroz cijelo promatrano razdoblje ukazuje na uspješnost u postizanju zadanog (stabilan tečaj) što je prikazano u tablici 4 . Novčana masa rasla je u čitavom promatranom razdoblju, izuzev 2008. i 2009., a brži porast može se uočiti do 2007. i od 2015. Takav kontinuirani pozitivni trend djelomično se može pripisati neposrednom utjecaju najčešće ekspanzivne monetarne politike HNB-a. Stopa inflacije kao ključni pokazatelj u postizanju osnovnog cilja HNB-a o stabilnosti cijena bila je povećana u godinama od 2004. do 2009. i u godinama od 2011. do 2013. U preostalim godinama može je se ocijeniti stabilnom u odnosu na standard ESB-a pri kojem je stopa inflacije ispod, ali blizu $2 \%$. Kreditiranje trgovačkim društvima bilo je ubrzano od 2002. do 2011., odnosno usporeno od 2011. do 2018. uz stagnaciju u 2019. Kreditiranje stanovništva bilježi ubrzanje od 2002. do 2008., usporenje od 2008. do 2009., ubrzanje od 2009 do 2011, usporenje od 2011. do 2016., ubrzanje od 2017. do 2018. te stagnaciju u 2019. Udio duga opće države u BDP-u rastao je od 2002. do 2004., stagnirao 2005. i 
zatim blago porastao od 2005. do 2007. Od 2007. do 2014. dug je kontinuirano rastao, a od 2014. do kraja promatranog razdoblja kontinuirano je padao. Drugim riječima, dug opće države u BDP-u uglavnom je rastao do 2014., odnosno od tada se kontinuirano smanjuje. U promatranom razdoblju od 2002. do 2019. tečaj eura u odnosu na hrvatsku kunu ojačao je za $0,004 \%$, novčana masa se povećala za $34,19 \%$, stopa inflacije smanjila za 52,94 \%, kreditiranje trgovačkih društava povećalo za 60,54 \%, kreditiranje stanovništva povećalo za 198,61 \%, a udio duga opće države u BDP-u također povećalo za 97,30 \%. Rezultati višestruke regresijske analize koji ukazuju na signifikantnost ili nesignifikantnost svake nezavisne varijable (novčane mase, inflacije, kredita stanovništvu, kredita trgovačkim društvima i udjela duga u BDP-u) pojedinačno na zavisnu varijablu (tečaj), prikazani su u tablici 5. P-vrijednost dvosmjernog testa ukazuje na nesignifikantnost svih varijabli (p- vrijednost veća od 0,05 ) osim varijable udjela duga opće države u BDP-u (p-vrijednost manja od 0,05) s obzirom na tečaj. Istovremeno p-vrijednost jednosmjernog testa ukazuje na graničnu signifikantnost još jedne varijable na tečaj, novčane mase M1. Pritom se kod udjela duga opće države u BDP-u radi o pozitivnoj, a kod novčane mase o negativnoj korelaciji s tečajem.

Tablica 5. Rezultati višestruke regresijske analize (metoda najmanjih kvadrata)

\begin{tabular}{cccccc}
\multicolumn{5}{c}{ Multiple Linear Regression - Ordinary Least Squares } \\
Variable & Parameter & S.D. & $\begin{array}{c}\text { T-STAT HO: pa- } \\
\text { rameter }=0\end{array}$ & 2-tail p-value & 1-tail p-value \\
\hline (Intercept) & +7.524 & 0.169 & $+4.4510 \mathrm{e}+01$ & $1.078 \mathrm{e}-14$ & $5.388 \mathrm{e}-15$ \\
\hline M1 & -0.003031 & 0.001691 & $-1.7920 \mathrm{e}+00$ & 0.09832 & 0.04916 \\
\hline IFL & +0.007023 & 0.01948 & $+3.6060 \mathrm{e}-01$ & 0.7247 & 0.3623 \\
\hline Ktd & -0.004341 & 0.005589 & $-7.7670 \mathrm{e}-01$ & 0.4524 & 0.2262 \\
\hline Kst & $-1.695 \mathrm{e}-06$ & 0.004432 & $-3.8250 \mathrm{e}-04$ & 0.9997 & 0.4999 \\
\hline 'Dug/BDP' & +0.008787 & 0.002208 & $+3.9800 \mathrm{e}+00$ & 0.001828 & 0.0009138 \\
\hline
\end{tabular}

S obzirom na to da je udio duga opće države u BDP-u jedina signifikantna varijabla u modelu, isključenjem ostalih nesignifikantnih varijabli oblikovan je model jednostruke regresijske analize (prilog 1 i 2) koji je zapravo pokazao da je utjecaj udjela duga opće države u BDP-u na tečaj statistički beznačajan. Drugim riječima, model je potvrdio da praktički ne postoji neka nezavisna varijabla koja bi mogla prisiliti HNB na drugačiju tečajnu politiku (širi kanal kolebanja). Ulaskom u ERM II i definiranjem središnjeg pariteta euro/kuna $=7,53450$ stvorili su se novi institucionalni uvjeti za očuvanje iste tečajne politike do konačnog uvođenja eura. Središnji paritet, kao i sve pozitivne i negativne tečajne razlike koje će se realizirati prilikom uvođenja eura, izvan su cilja i okvira interesa ovoga članka, ali to svakako predstavlja jedno od ključnih pitanja o kojem se u javnom političkom i stručnom prostoru ne govori. 
Prilog 1. Rezultati linearne regresijske analize

\begin{tabular}{|c|c|c|c|c|}
\hline \multicolumn{5}{|c|}{ Linear Regression Model } \\
\hline \multicolumn{5}{|l|}{$Y \sim X)$} \\
\hline \multicolumn{5}{|l|}{ coefficients: } \\
\hline & Estimate & Std. Error & t value & $\operatorname{Pr}(>|t|)$ \\
\hline (Intercept) & 7.286 & 0.092 & 79.562 & 0 \\
\hline x & 0.003 & 0.001 & 2.302 & 0.035 \\
\hline \multicolumn{5}{|l|}{--} \\
\hline Residual Std. Err. & 0.115 on $16 \mathrm{df}$ & & & \\
\hline Multiple R-sq. & 0.249 & & & \\
\hline 95\% Cl Multiple R-sq. & {$[0.002,0.739]$} & & & \\
\hline Adjusted R-sq. & 0.202 & & & \\
\hline
\end{tabular}

Izvor: autori.

Prilog 2. ANOVA statistika

\begin{tabular}{cccccc} 
& \multicolumn{5}{c}{ ANOVA Statistics } \\
& Df & Sum Sq & Mean Sq & F value & $\operatorname{Pr}(>\mathrm{F})$ \\
\hline Dug & 1 & 0.07 & 0.07 & 5.298 & 0.035 \\
\hline Residuals & 16 & 0.212 & 0.013 & & \\
\hline
\end{tabular}

Izvor: autori.

\section{Zaključak}

Ovim je radom, stavljanjem u odnos fiskalnih i monetarnih pokazatelja RH i nominalnih pokazatelja, prikazana dosegnuta razina nominalne konvergencije Hrvatske. Uočeno je da RH ni u jednoj od promatranih godina ne ispunjava sve kriterije nominalne konvergencije. U radu se obradila operativna prilagodba HNB-a pristupanju Eurosustavu kao rezultat pristupanja Hrvatske europodručju. Operativna je prilagodba povezana sa zamjenom instrumenata za provođenje monetarne politike HNB-a s instrumentima ESB-a, odnosno s preuzimanjem jedinstvene monetarne politike ESB-a. Stupanj prilagodbe HNB-a u odnosu na sustav ESB-a ovisit će o sličnostima ili različitostima između sustava. Shodno tome, najzahtjevnija prilagodba odnosit će se na sustav obveznih pričuva s obzirom na to da stopa obvezne pričuve HNB-a iznosi $9 \%$ (do nedavno $12 \%$ ), a Eurosustava $1 \%$. Zahtjevniji stupanj prilagodbe odnosit će se također na područje nekonvencionalne monetarne politike. ESB raspolaže daleko širom paletom nekonvencionalnih instrumenata i mjera te je sa samim provođenjem nekonvencionalne monetarne politike započela prije desetak godina. S druge strane HNB je s provođenjem takve nekonvencionalne politike započeo ove godine kupnjom državnih obveznica na sekundarnom tržištu. Time je potvrđena hipoteza 
postavljena na početku rada da makroekonomski pokazatelji i pokazatelji makroprudencijalne dijagnostike odstupaju od nominalnih. Shodno iznimno visokom stupnju euroizacije i snažnoj izloženosti čitavog domaćeg sektora valutnom riziku, operativni okvir HNB-a postavljen je na način da najefikasnije podržava ostvarivanje i održavanje stabilnosti cijena kao primarnog cilja monetarne politike. Sukladno nominalnom sidru HNB-a, kojim dakle djeluje na ostvarivanje i održavanje stabilnih cijena, najčešće korištene operacije u operativnom provođenju monetarne politike HNB-a jesu operacije na otvorenom tržištu - devizne transakcije. Takvo nominalno sidro odabrano je u skladu s karakterističnim obilježjima hrvatskog gospodarstva. Hrvatska je zemlja s iznimno visokom stopom euroiziranosti, a hrvatsko je gospodarstvo malo i otvoreno. Održavanje stabilnog tečaja kune u odnosu na euro važno je razmatrati s dvaju aspekata. Prvo, s aspekta velikog zaduženja svih domaćih sektora koje je dominantno u eurima, iz čega u slučaju izraženije deprecijacije kune proizlazi rizik od povećanog tereta otplate duga. Drugo, s aspekta izvoza, s obzirom na to da bi izraženija aprecijacija kune negativno utjecala na konkurentnost hrvatskog gospodarstva. S obzirom na to da izraženije fluktuiranje tečaja kune u odnosu na euro generalno predstavlja prijetnju za financijsku i monetarnu stabilnost Republike Hrvatske, kao logično rješenje uzeto je održavanje tečaja stabilnim. Statistička analiza u ovom radu pokazala je da odabrane nezavisne varijable nemaju signifikantan utjecaj na tečaj, izuzev udjela duga u BDP-u (iako statistički blago) i novčane mase koja se pokazala granično signifikantnom. Tako da je regresijskom analizom zapravo potvrđena specifičnost tečaja kao makroekonomskog cilja u provođenju hrvatske monetarne politike na kojeg ipak u najvećoj mjeri utjecaj ostvaruje HNB operativnim provođenjem. Također, unatoč uvjetima makroekonomskih i financijskih šokova uzrokovanim pandemijom koronavirusa, Hrvatska se 10. srpnja ove godine priključila ERM-u II. čime je napravila ključni korak prema uvođenju eura. S obzirom na minimalni propisani boravak u tečajnom mehanizmu, Hrvatska euro neće moći uvesti u naredne dvije godine. Time se zapravo potvrdila druga hipoteza da financijska i monetarna stabilnost u uvjetima vanjskih šokova nisu bili eliminatorni kriteriji u dinamici operativne prilagodbe Hrvatske. 


\section{Literatura}

1. Brkić, M. i Šabić, A. 2018. Je li euro oprimalna valuta za Hrvatsku: ocjena korištenjem teorije optimalnih valutnih područja. Privredna kretanja i ekonomska politika, 27 (1/142): 9-70.

2. Čehulić, Z. i Hrbić, R. 2019. The impact of adopting the euro on the Croatian economy: What can be learned from other countries? Notitia - journal for economic, business and social issues, 5 .

3. Corić, T. i Deskar-Škrbić, M. 2017. Croatian path towards the ERM2: why, when and what can we learn from our peers? file://C:/Users/Dell/AppData/Local/Temp/KB_0021.pdf.

4. Derado, D. 2009. Financial integration and financial crisis: Croatia approaching the EMU. Financial Theory and Practice, 33 (3): 299-328.

5. Deskar-Škrbić, M., Kotorac, K. i Kunovac, D. 2019. The Third Round of the Euro Area Enlargement: Are the Candidates Ready? https://www.hnb.hr/documents/ 20182/ 2838610/w-057.pdf/dda18653-5417-11cb-c8d7-a29c564ed5b7.

6. Europska središnja banka. 2018. Izvješće o konvergenciji. https://www.ecb.europa.eu/ pub/pdf/conrep/ecb.cr201805.hr.pdf.

7. Europska središnja banka. 2020. Izvješće o konvergenciji. https://www.ecb.europa.eu/ pub/convergence/html/ecb.cr202006 9fefc8d4c0.hr.html\#toc3.

8. Hrvatska narodna banka. 2015b. Ciljevi monetarne politike. https://www.hnb.hr/temeljne-funkcije/monetarna-politika/ciljevi.

9. Hrvatska narodna banka. 2015a. Uloga HNB-a. https://www.hnb.hr/-/o-financijskojstabilnosti.

10. Kotorac, K., Kunovac, D. i Ravnik, R. 2017. Usklađenost poslovnih ciklusa i ekonomskih šokova između Hrvatske i država europodručja. https://euro.hnb.hr/ documents/2070751/2104183/i-051.pdf/cc59ee57-c63a-4d49-8798-6fc7107aec7d.

11. Marić, Ž. 2015. Maastrichtski kriteriji konvergencije s posebnim osvrtom na Bosnu i Hercegovinu. Mostariensia, 19 (2): 127-150.

12. Sorić, M. 2007. Utjecaj volatilnosti tečaja kune na Hrvatski izvoz. Financijska teorija $i$ praksa, 31 (4): 347-363.

13. Toader, V. i Guîdu, V. 2012. The study of nominal convergence in European Union. Procedia Economics and Finance, 3: 871-876.

14. Vlada Republike Hrvatske i Hrvatska narodna banka. 2017. Strategija za uvođenje eura kao službene valute u Hrvatskoj. https://vlada.gov.hr/UserDocsImages/Vijesti/2017/10\%20listopad/30\%20listopada/Strategija\%20za\%20uvo\%C4\%91enje\%20 eura\%20kao\%20sluz\%CC\%8Cbene\%20valute\%20u\%20Hrvatskoj.pdf.

15. Wessa, P. 2020. Free Statistics Software, Office for Research Development and Education. Version 1.2. 


\title{
Nominal convergence and dynamics of the adjustment of the Republic of Croatia to the euro area
}

\begin{abstract}
In order to introduce the euro as its official currency, a candidate country for the euro area must meet the Maastricht criteria or nominal convergence criteria and thus prove a sufficient level of nominal convergence. The convergence criteria represent a sort of protection of the euro area from the risk of macroeconomic instability, i.e. a sufficient level of nominal convergence indicates the level of readiness of the candidate country for integration into the monetary regime of the euro area. This paper specifically analyzes the dynamics of the adjustment of the Republic of Croatia around the process of accession to the euro area. This primarily included monetary and fiscal positioning of the state in relation to nominal criteria. Given that the EUR/HRK exchange rate is the nominal anchor of the entire monetary policy to this day and that the foreign exchange transactions are crucial in creation and withdrawal of reserve money, the focus of this research is the exchange rate of the Croatian kuna against the euro. Although the exchange rate of the Croatian kuna against the euro is freely formed on the foreign exchange market, depending on foreign exchange supply and demand, the central bank joins the foreign exchange market in cases of stronger exchange rate fluctuations. The fact that the CNB pursues a policy of so-called managed floating exchange rate and that the nominal exchange rate of Croatian kuna against the euro is stable, was also confirmed by a model applying multiple regression analysis of independent variables that characterize monetary and fiscal conditions no impact on the exchange rate of the Croatian kuna against the euro was made. This has obviously been and remains the primary and exclusive issue of the central bank's exchange rate policy, regardless of the exchange rate's interaction with other variables or the economic and financial consequences of such an exchange rate policy.
\end{abstract}

Key words: euro area, nominal convergence, convergence criteria, exchange rate EUR/HRK 